\title{
Current Understanding of Endophytes: Their Relevance, Importance, and Industrial Potentials
}

\author{
Shashank A. Tidke* ${ }^{1}$, Rakesh Kumar KL ${ }^{1}$, D.Ramakrishna ${ }^{1}$, \\ S.Kiran ${ }^{1}$, G.Kosturkova ${ }^{2}$ and Ravishankar A. Gokare ${ }^{1}$ \\ ${ }^{I}$ Department of Biotechnology, Dayananda Sagar College of Engineering Kumaraswamy Layout, Bengaluru \\ 560078 India \\ ${ }^{2}$ Plant Biotechnology, In Vitro Development and Genome Regulation Institute of Plant Physiology and \\ Genetics, Bulgaria Academy of Sciences 1113 Sofia, Bulgaria
}

\begin{abstract}
Endophytes are microorganisms which live in endogenous association with host plants. They occur in plant of various habitats. This review focuses on the types of endophytes their classification and characterization and their beneficial effects on the plant productivity. Expression of various biochemical molecules in plants is a subject of intense research. Endophytes are known to produce metabolites of utility value for various applications. Biotechnological production of endophyte derived compounds both under in vitro \& in vivo conditions have been investigated. The co-evolution of plant with endophytic association is beginnings to be understood. The current research on endophytes has been enumerated for comprehensive understanding of the topic.
\end{abstract}

Keywords: Endophytes, classification, Secondary Metabolites, bioactive compounds.

\section{Introduction}

In the middle of the nineteenth century, there were reports about existence of endophytes ; however it had not captured much attention until lots of livestock's were poisoned because of feed with grass infected by endophytes [1]. The term endophyte was proposed by de Bary, in 1866. They were first described in Lolium temulentum . The presence of bacteria resident within the tissues of healthy plants was first reported at 1926 [2]. Endophytes were discovered by freeman $(1904)^{3}$, who identified an endophytic fungus in Persain darnel (annual grass). Grasses with high endophyte content were often resistant to the attack by certain insects. It was estimated that over one million species of endophytes exists [4]. Endophytes constitute a remarkably large group of microorganism ubiquitous in plants and maintain a close association with their host for at least a part of their life cycle. During this association, none of the interacting partners are discernibly harmed [5]. Approximately 300,000 plant species growing in unexplored areas on the earth are host to one or more endophytes [6]. And the presence of biodiverse endophytes in enormous number plays a significant role on ecosystem in both the tropical and temperate rainforest [7]. ${ }^{6}$ Strobel et al (2004) reported that the production of bioactive substances by endophytes is related to the independent evaluation of these microorganisms, which may have integrated genetic information from higher plants, allowing them to adapt to plant host and take out some function such as protection from pathogen, insects and grazing animals. Enormous biological diversity of endophytes coupled to their ability to biosynthesize bioactive secondary metabolites has provided the impetus for a number of investigations.

Endophytes are chemical synthesizers inside the plants [8]. Endophytes give a wide variety of bioactive secondary metabolites with distinctive structures, including alkaloids, benzopyranones, chinones ,flavonoids, phenolic acids, quinones, steroids, terpenoids, tetralones, xanthones and others [9]. Such bioactive metabolites find wide-ranging application as agrochemicals, antibiotics, immunosuppressants, antiparasitics, antioxidants and anticancer agents. Endophytes are also found to produce various bioactive substances which have great value in ecology, medicine and pathology [10]. An endophyte may provide defense and endurance condition to their host plant by producing a plethora of substances which, once isolated and characterized may also have potential for use in industry, agriculture and medicine $[6,11,12,13]$.

The scope of the review encompasses the information from published literature only on the distribution of endophytes, their role in plants, and utility for human needs. This compilation of the reported literature provides a bird's eye view of the scenario of endophytes and would suggest ways of their utility for various basic and applied research. 


\section{Definition, Distribution and Origin}

Endophytic microbes exist within plants for at least a part of their life cycle without causing any visible sign of disease [14, 11]. ${ }^{15}$ Sikora et al 2007 expanded the definition of endophyte, as an organism colonized in the internal tissue of a plant throughout its life cycle no matter whether it was useful, harmful or unbiased to its host. Endophyte originally was a concept of ecology but is an integral natural part of plant-micro ecology system [16]. An endophytic fungus exists in all plants and is widespread in nature [17]. According to Dreyfuss and Chapela $(1994)^{18}$ there are millions of endophytic fungi existing in special circumstance of 270,000 to 4,000,000 kinds of microtubule plant cells and intercellular space. Isolation of endophytes from many plants such as tomato, pepper, Eucommia ulmoides and Taxus yunnanensis distributed in roots, stems, leaves, fruits and seed are reported. A significant discovery of the endphytic fungus Neotyphodium coenophialum as the causative organsism of "fescue toxicosis" a syndrome suffered by cattle fed in pastures of the grass Festuca arundinacea provided direction to research on this topic (Bacon et al 1977). ${ }^{19}$ Schardl et al $(2004)^{20}$ found that infected plants contained a number of poisonous alkaloids however Neotyphodium species might be beneficial to their plant host, increasing their tolerance of biotic and abiotic stress factors.

\section{Biodiversity Of Endophytes:}

All the reported endophytes are fungi or bacteria (including actinomycetes). Endophytes are classified according to the microbe, mainly including endophytic fungi, endophytic bacteria and endophytic actinomyces [6].

3.1 Endophytic fungi: An endophytic fungus is a various polyphyletic group of microorganisms; they can increase asymptomatically in the tissues of plants including stems, leaves and roots. Bacon and White (2000) ${ }^{11}$ reported that an endophytic fungus lives in mycelial form in biological organization with in the living plant, at least for some time. Therefore the minimal requirement before a fungus is termed an endophyte should be the demonstration of its hyphae in living tissue. Sathe and Raghukumar $(1999)^{21}$ used a bleaching and a staining technique for demonstrating intracellular hyphae in seagrass. Senthikumar et al (2000) ${ }^{22}$ used acridine orange fluorescence microscopy for rapid visualization of hyphae in hand cut sections of orchid mycorrhizal roots. Since identification of a fungus from hyphal features alone is rarely possible, the identification techniques will require method of immunofluorescence detection, DNA sequencing and comparison of sequence to homologous sequence registered in gene bank. Endophytic fungi, a polyphyletic group of highly diverse, primarily ascomycetous fungi are defined functionally by their occurrence within asymptomatic tissue of plants. They are found to associate with above-ground tissue of liverwort, hornwort, mosses, lycophytes, equisetopsids, fern and seed plants from the arctic to the tropics, and from agriculture fields to the most diverse tropical forest [23]. Endophytic fungal association differ from mycorrhizae primarily by the absence of a localized interface of specialized hyphae, the absence of synchronized plant-fungus development, and the lack of plant benefits from nutrient transfer. Plants may benefit indirectly from endophytes by increased resistance to herbivores, pathogen or stress or by other unknown mechanisms [24]. Many endophytes have the potential to synthesize various bioactive metabolites may, directly or indirectly, be used as therapeutic agents against numerous diseases [25]. Some studies have shown that endophytic fungi are able to protect their host plant from drought conditions [26]. Waller et al $(2005)^{27}$ observed salt tolerance in infected plants with endophytes. Endophytic fungi also increase heat tolerance in their host. Redman et al (2002) ${ }^{28}$ reported that endophytes works as biological trigger to stimulate the stress response more rapidly and strongly than non-symbiotic plants. Stoyke and Currah $(1991)^{29}$ initiated the form taxon "dark septate endophytes" (DSE) and used it for fungi that form moderately or completely melanised and having septate thalli within healthy root tissues. The taxon "DSE" serves primarily to differentiate these fungi from endophytes with septate and hyaline hyphae, from fungi having sparse septation and hyaline hyphae that are characteristic of arbuscular mycorrhizal fungi. Taxonomic assignment of many DSE is problematic because sexual and asexual reproductive structures are either absent, rare, or are produced only under specific condition [23]. Non-mycorrhizal and nonDSE fungi also occur within plant tissues and such endophytic fungi were found to lack the distinctive morphology of both mycorrhizal symbionts and DSE [30]. Stierle et al (1993) ${ }^{31}$ was the first to isolate endophytic fungi (Taxomyces anderanae) from a medicinal plant (Taxus brevifolia)[16]. Huang et al $(2007)^{4}$ also got a total 42 endophytic fungi strain from Nerium oleander $L$. Endophytic fungi also exist in the marine plants [33]. The endophytic and obligate marine fungus Ascochyta salicorniae was reported in green algae [32]. Endophytic fungi also are adopted widely for their application in promoting plant growth and protecting the plant to reduce diseases and insect pests. Strobel et al $(1997)^{33}$ reported that a few species of endophytic fungi have been identified as sources of anticancer, anti-diabetic, insecticidal and immunosuppressive compounds. Endophytic fungi may also produce 
metabolites with thermo protective role. Fungal endophytes consist of two basic ecological groups: Balansiaceous or "Grass endophytes" and Non-Balansiaceous.

3.1.1.Balansiaceous endophytes or Grass endophytes: They are the best studied groups due to their ecological and economic importance. Balansiaceous endophytes form a distinctive group of closely related fungi with ecological requirements and adaptation discrete from those of other endophytes [34]. They grow systemically, epicuticularly and intercellularly within all aboveground plant organs of grasses, resulting in vertical transmission of the endophytes through the seed. They belong to the clavicipitaceous genera Epichloe and Balansia, and their anamorphs Neotyphodium and Ephelis [20]. The balansiaceous endophytes produce a diverse array of secondary metabolites. The toxic alkaloids consist of the anti-insect alkaloids peramine and lolines, and the anti-vertebrate alkaloids loliterm B and ergovaline [35]. The primary benefits for the fungal partner are nutritional, but also include fortification from abiotic stress, such as desiccation [11] and from competing epiphytic organisms [36].The advantage of the interaction for plant is protection against herbivore by toxic alkaloids produced by fungal endophytes during symbiotic association, and they also mediate induced resistance through activation of the host defense through constitutive and resistance [37]. Bacon and White (2000) ${ }^{11}$ summarized the colonisation of the host is primarily intercellular; the endophytes are dependent on nutrient of the apoplast for growth. Pan and Clay $(2004)^{38}$ studied distribution and nutrition of the endophytes in planta. $\mathrm{C}^{14}$ movement of labelled leaves was better for infected stolons than for those of non-infected plants [26]. Sinclair \& Cerkauskas (1996) ${ }^{39}$ reported that some balansiaceous endophytes contribute nothing to the fitness of their hosts and may even be antagonistic. Schardl $(2001)^{35}$ reported through physiological signaling as communication channels in endophytes , E. festucae and host plants.

3.1.2. Non-Balansiaceous endophytes: They are diverse, both phylogenetically and with respect to lifehistory strategy. Non -balansiaceous endophytes belong to the Ascomycota and colonize either inter or intracellular, localized or systematic [24]. In the case of the non-balansiaceous, types the term 'endophyte' usually refers to a fungus with accomplished of cryptic activity of plant tissue [24]. The fungi are not obligate host specific; they have a certain level of adaptation to different hosts. While others are more specific and can only be found in specific organs of specific plant [24]. Some endophytes have been found to be nonaggressive, in not causing disease [40]. The non balansiaceous endophytes are a highly diverse group and encompass a broad range of fungi from the Ascomycetes and to a lesser extent the Basidiomycetes. Members of this group often have a broad host range even at the species level; they are able to colonize monocotyledons and dicotyledons. Some nonclavicipitaceous endophytes are highly host specialized and are localized within particular organs or cells of a host, whilst other non-clavicipitaceous endophytes are non-host specific and some colonies throughout the host tissue[41]. The separation of endophytes into these groups is effective for the balansiaceous endophytes but the toxonomic range and variety of behaviors within the non -balacious endophytes suggest that further division could be made within this group. Rodriguez et al $(2009)^{40}$ reclassified the divisions of endophytes; separating them into four classes. Class I incorporates constitutive mutualists (balansiaceous endophytes); Class II and III correspond to inducible mutalists whilst Class IV coincides with dark septate root colonizing fungi.

Class I: The balansiaceous fungi share an intimate relationship with their host. They are highly host specific, exhibiting extremely high among host diversity but very low within host diversity, to the extent that different isolates can be associated with individual host units [42, 40, 43] reported the fungi inhabit the intercellular spaces of aerial plant organs and the extent of fungal colonisation is dependent on the level of stress the host is experiencing. Some Class 1 endophytes have lost the ability to reproduce sexually and are transmitted via host seed [26] and horizontally through the production of epiphyllous conidia [44]. The releationship between the host and class I fungal symbiont reflects a mutalistic bond with the fungus receiving nutrients, shelter and protection from its host. The advantage of the endophyte interaction is apparent with increased survivability in the host when experiencing biotic or abiotic stress and this coincides with increased endophytic colonisation of the host tissues [45].

Class II : Members of Class II are able to extensively colonize a broad range of hosts and can disseminate vertically (through host seed) and horizontally (through host rhizomes) and fruit on senescing host tissue [46]. Class II endophytes can reside throughout the entire host plant, colonising rhizome, root and shoot. The extent to which they inhabit their host positively correlates with the level of stress the host is experiencing [40].Member of class II have been shown to increase host tolerance and growth in extreme artificial environments such as extreme temperature, salinity and drought [47]. Class II endophytes are also able to provide protection against fungal antagonists, both through the 
production of metabolites toxic to fungi and stimulation of plant defense responses [48]. Class II fungi are also associated with saprotrophic behaviour, increasing the senescence (degradation/ breakdown) of senescing host tissues [49].

Class III: Class III fungi typically have a broad host range and a colonization pattern within the host of highly localized infections that occur in the above ground portions of the plant [50, 40]. Class III fungi may provide protection to its host from other invading fungal species and/or effectively outcompete other fungal species; pathogenic or otherwise [2]. However, if the host is experiencing stress such as drought stress, these endophytes behave pathogenically (able to cause diseases) [2, 41].

Class IV: Class IV consists of fungi from the Ascomycota. They are generally asexual and are characterized by dark melanised septa, occupying only inter- and intracellular spaces in plant roots (that may also be colonized by mycorrhizal fungi) [40]. Class IV endophytes display little to no host specificity and are widely associated with hosts in stressed environments throughout the world [40.51]. Class IV endophytes may benefit hosts in stressful environments and possibly aid in prevention of infection by antagonistic fungi i.e. disease protection [51]. The diagram (Fig 1) which has been published by [5] is adapted for understanding of the various endophyte classes.

3.2. Endophytic bacteria: Endophytic bacteria arise at inferior population densities than rhizospheric bacteria or bacterial pathogens [47]. It has not been established whether plants profit from an endophyte than from a rhizospheric bacterium or if it is more beneficial for bacteria to suit endophytic compared with rhizospheric. Endophytic bacteria might be better protected from environmental stresses than rhizospheric bacteria [2].

Endophytic bacteria in a particular plant host are not classified to a single species but include several genera and species. Bacterial endophytes are able to repressing nematode proliferation thus would help to other crops in rotation with the host plants [53]. Endophytic bacteria usually exist in intercellular space and vascular tissue of the plant. Lots of research of isolating endophytic bacteria from various plants, such as cotton, sweet corn cultivars and pea cultivars are reported [54]. Nonsymbiotic endophytic bacterial strains were isolated from 150 soybean root nodules [55 \&56]. More than 129 kinds of the endophytic bacteria were isolated from different crop plants, including both Gram-negative and Gram-positive species representing over 54 genera. The major bacterial taxa belong to the former Pseudomonas group and Enterobacteriaceae [57]. Gaiero et al (2013) ${ }^{58}$ studied bacterial root endophytes and plant growth promotion. They have observed endophytic community structure (species diversity, richness and relative abundances) within the plant is lively and is partial by abiotic and biotic factors such as soil conditions, biogeography ,plant species , microbe - microbe interaction and plant microbe interaction. Plant - growth - promoting bacterial endophytes (PGPBs) have been identified, but the predictive success at positively influencing plant growth in field condition has been limited. Rosenblueth and Romeo (2004) ${ }^{47}$ studied molecular techniques on bacterial endophytes and their interaction with hosts. They have concluded that endophytes promote plant growth and yield, suppress pathogens may help to remove contaminants, solubilize phosphate, or contribute assemble nitrogen to plants. Molecular analysis showed that defense responses limit bacterial population inside plants [59]. Gram-negative enteropathogenic bacteria can successfully colonize animals, humans and plants. Gramnegative enteropathogenic bacteria are divided into two species: Salmonella bongori and Salmonella enterica, about some hundred isolates, which are usually named after the place of origin. S. enteric is also divided into seven subspecie [60], one of them, S. enterica sub sp. enterica, is the foremost cause of Salmonellosis in humans. The most common mode of infection is intake of contaminated food or water. In addition, many reports have linked food poisoning with the utilization of Salmonellacontaminated raw vegetables and fruits. Adam et al (2012) ${ }^{61}$ reported that on Plants are alternative hosts for Salmonella. They concluded that the growing number of human infections with pathogenic bacteria derived from vegetables and fruits raise the question of the host specificity mechanisms of these bacteria. Cooley et al $(2003)^{62}$ reported that Salmonella not only passively survive, but also actively infect plants. In addition, infection of plants depends on the active repression of the host immune responses by Salmonella. Some human pathogens, such as Salmonella spp., have been found as endophytes.

3.4. Endophytic actinomyces: Plant associated bacteria (including actinomycetes) act as agents to stimulate plant growth and management of soil and plant health. The most endophytic actinomyces isolated is Streptomyces, which usually colonized in the roots, stems, and leaves of plant with highest in root [10]. Medicinal plant is the chief resource of isolating endophytic actinomyces which can stimulate secondary metabolite of very important value. Most of endophytic actinomycetes latently live in the inner tissues of nonsymptomatic plants without causing any undesirable effects to the host [63]. Endophytic actinomycetes have been verified to develop and promote the plant growth as well as to 
decrease the disease symptoms and different environmental stresses. Stoyke and Currah $(1991)^{64}$ have evaluated the performance of endophytes in farm system. They concluded that the endophyte provides the plant with protection from a range of insect pests by producing alkaloids, some of which are toxic to grazing animals.

\section{Isolation And Preservation Of Endophytes:}

4.1. Isolation of endophytes: The method most frequently utilized to detect and quantify endophytes involves isolation from surface-sterilized host plant tissues. Endophytic isolation is carried out under aseptic conditions. Different symptomless parts of the plant such as stem cuttings, fruits and roots have been used for the isolation of endophytes [65]. Surface sterilization is completed by consecutively rinsing the plant material with $70 \%$ ethanol for 30 seconds, then with $0.01 \%$ mercuric chloride for 5 minutes and finally with sterile distilled water for 2-3 times. Plant material dried in between the folds of sterile filter papers [66]. The tissue is either inoculated on to PDA medium directly or after grinding

4.2 .Preservation of endophytes: Preservation and long term maintenance of fungi on certain culture media is laborious and requires utmost care. Various alternative and reliable methods for fungal conservation have been developed from time to time e.g. preservation in paraffin oil, sand, silica gel, dried host tissues, distilled water, lyophilization and liquid nitrogen conservation. The maintenance and storage of pure strains on agar slant. The grasses endophytes have been recommended to be stored in Eppendorf tubes topped by mineral oil [30]. Therefore, endophytes in general are preserved by following different techniques applied for preserving general fungi, like in $15 \%$ glycerol $\left(\right.$ at $\left.-70^{\circ} \mathrm{C}\right)$, $20 \%$ glycerol $\left(-20^{\circ} \mathrm{C}\right)$,silica gel $\left(10^{\circ} \mathrm{C}\right)$,in lyophilized form at $-20^{\circ} \mathrm{C}$ and on PDA slant $[67,68$, 69].Preservation of pure strain without losing its metabolic potential activities has become essential for further exploitation in various applied disciplines. Several methods have been reported from time to time for the preservation of fungi belonging to different groups.

4.3. Mineral Oil: Preservation of fungal strains under mineral oil has been considered as one of the most reliable and effective techniques. The mineral oil prevents dehydration and slows down the metabolism which leads to slow growth $[70,71,72,73]$. Borba and Rodrigues $(2003)^{73}$ reported successful preservation of 11 coelomycetous endophytes under mineral oil, which although remained viable but lost sporulating ability. It has been observed that recovery of strains preserved in mineral oil varies greatly with the group of fungi to be stored at different temperatures.

4.5.Sterile Distilled Water: The preservation of fungi in sterile distilled water is one of the simplest, easiest and inexpensive methods for the preservation of different group of fungi. Ascomycetes including their mitosporic forms survived up to 10 years when stored in sterile distilled water at $20^{\circ} \mathrm{C}[74]$. Survival of fungal strain after 12 months of preservation in $4 \mathrm{ml}$ of sterile distilled water in sterile glass flasks was reported [75]. All the endophytic strains preserved in distilled water at $17^{\circ} \mathrm{C}$ were found viable after 6 months.

15\% Glycerol: Preservation of culture in glycerol (at $-20,-70 .-80^{\circ} \mathrm{C}$ ) is the widely accepted method. Since the rate of metabolism is arrested at lower temperature, this method is good for long term preservation. Many endophytes have been preserved by this method [76, 73].

4.6. PDA Slants: The preservation of fungal cultures on agar slants is a widely used classical method for preservation of fungi and in this method cultures are generally stored between $4-20^{\circ} \mathrm{C}[55,68]$.

\section{Identification Of Endophytes:}

Endophytic fungal strain were identified based on the morphology of fungal culture colony or hyphae spores characteristics and reproductive structure [77]. The identities of some major groups were subsequently verified with molecular methods. For inducing sporulation, the fungal strains were separately inoculated on potato dextrose agar, potato carrot agar, and water agar in Petri dishes. Measurement of all fungal characters were made in water mount and the slides were subsequently mounted in lactophenol and sealed with nail vanish or paraflim [77]. Those cultures that failed to sporulate were grouped as sterile mycelia and divided into different morph species according to their culture characteristics [77]. Most of the new methods have been used for identification of endophytic fungi i.e. polymerase chain reaction (PCR) and subsequent DNA sequencing. Identification of fungal endophytes can best be accomplished by amplification of Internal Transcribe Spacer (ITS) region, which are repeating unit of DNA encoding ribosomal RNA. Sequencing the amplified DNA and comparing it with the database can help determine whether or not the specimen is novel; if the sequence is known, then the species can be identified. Promputtha et al $(2007)^{78}$ reported fungal endophytes from soybean leaves by using fragment plating and the novel dilution -to-extinction culturing of isolation techniques. These techniques have increased the species frequency of isolates and diversity. These fungal endophytes were identified by analysis of the internal transcribed spacer (ITS) 
of the ribosomal DNA (rDNA). The genera Ampelomyces, Annulohypoxylone, Guignardia,Leptospora,Magnaporthe, Ophiognomonia, Paracomiothyium , phaeosaeriopsis, Rhodotorula, Sporobolomyces and Xylaria for the first time were isolated from soybean; this suggests that soybean harbours novel and highly diverse fungi. Ampelomyces, Chaetomium and phomaglomerata are endophytic species that can play prospective functions in the biological control of soybean pathogen. ${ }^{78}$ have isolated the Enterobacter sakazakii,Erwinia sp, Klebsiella pneumonia $\gamma$ proteobacterial endophytes from soybean plants.

\section{Physiology Of Endophytes:}

Endophytic fungal societies adapt to different physiological conditions, in significance. These fungal communities were identified in the broad range of plant tissue. Several impartial fungal endophytes are slumbering pathogens which may be activated and cause infectious symptoms when the host plant is aged and/or stressed. In addition, plant's endophitic organizations with fungus can control environment by determination of plant and microbial biodiversity [23].The endophytic microbial populations play a vital role in the physiology of host plants. Hosts, colonized by endophytic frequently have more vigour due to secretion of plant growth promoting substances such as Indol 3 acetic acid (IAA) or cytokines and improvement of the hosts' absorption of nutritional nitrogen and phosphorus. Additionally, the endophyte partner can extensively enhance plant resistance to biotic and abiotic challenges [79]. These beneficial features has been observed in infected plants exposed to several abiotic stress such as drought (166), heavy metal [80], high salinity [47], As well as biotic one including microbial infections [47], insect pest [81] and herbivores attack [91].

\section{Interaction of Endophytes With Pathogen And Environmental Stress:}

Endophytic bacteria can reduce or avoid the harmful effects of assured pathogenic organisms. Diseases of fungal, bacterial, viral origin and in some case of damage caused by insects and nematodes can be reduced following prior inoculation with endophytes [31]. Production of inhibitory allelochemical, and induction of systematic resistance (ISR) in host plant to a broad spectrum of pathogen [82] and /or abiotic stress. Endophytic bacterial biocontrol agents can be divided into two groups i) Strains that comprehensively colonize the internal plant tissues and suppress invading pathogens by niche occupation, antibiosis, or both and ii) strains that primarily colonize the root cortex where they stimulate general plant defense/resistance mechanisms. More extensive and continuous colonization of plants might be required for endophytes of the first type because coincidence with pathogen propagules would be necessary for antagonism. According to Kusari and Spiteller (2012) the $^{5}$ effectiveness of endophytes as biological control agents (BCAs) is dependent on many factors. These factors include: host specificity, the population dynamics and example of host colonization, the capability to shift within host tissues, and the capability to stimulate systemic resistance. It is believed that certain endophytic bacteria trigger a phenomenon known as induced systemic resistance (ISR), which is phenotypically related to systemic-acquired resistance (SAR). SAR develops when plants fruitfully stimulate their defense mechanism in response to primary infection by a pathogen [85]. According to Van et al (1998) ${ }^{85}$ ISR is effective against diverse types of pathogens but diverge from SAR in that the inducing bacterium does not cause observable symptoms on the host plant. The endophytes are known to protect the plants from drought conditions by influencing the decrease of transpiration and also confers tolerance to drought through osmotic adjustments. Also the endophytes isolated from the saline environments and geothermal environments are reported to confer salt stress and also heat tolerance [86, 87].

VIII. Endophytes And Their Metabolites:

Endophytes provide a wide variety of bioactive secondary metabolites with exclusive structure, including alkaloids, benzopyranones, chinones, flavonoids, phenolic acids, quinones, steroids, terpenoids, tetralones, xanthones and others [139]. Such bioactive metabolites find wide -ranging application as agrochemicals, antibiotic, immunosuppressants, antiparastics, antioxidants and anticancer agents [88] ("Table 2")

\subsection{Endophyte chemicals:}

Ryegrass endophytes (AR1, NEA2, Endo5, standard and AR37) are reported to produce a range of chemicals as follows.

(Pasture Site 2012: copyright (C) 2012 by New Zealand Agriseeds Limited) (“Table1") and ("Fig 2") 


\section{Peramine:}

Peramine is an insecticide produce by the ryegrass endophyte. Peramine is believed to be the main chemical that gives ryegrass with endophyte its resistance to NZ's major pasture pests ${ }^{83}$ Aragentine stem weevil and pasture mealy bug. it is not believed to have any effect on animals.

\section{Lolitrem B:}

Lolitrem B is the chemical produced by standard endophyte, which causes ryegrass staggers in livestock, also known as summer staggers. Lolitrem B is also found in seed heads, so rank seedy pasture can also cause problems. Reeled is seen as tremoring in soft causes and reeling in more server cases. Animals are not usually killed by reels but may die through misadventure such as drowning in streams. Reels causes server management problem, particularly if stock must be regularly handled, eg milking cows. Reels usually clears up within 1-2 days if stock is given a diet containing no lolitrem B. Lolitrem B is very stable in hay or silage.

\section{Ergovaline:}

NEA2 and Endo5 endophytes both produce low levels of ergovaline, which are believed to have little or no effect on animal growth or health. Eragovaline also gives plants some resistance to black beetle and moderate resistance to root aphid. Eragovaline increase in spring with rising temperature and seed head development. Levels fall after reproductive growth and rise again in response to moisture stress.

\section{Janthitrems:}

Janthitrems are chemicals produced produce only by AR37 endophyte. Janthitrems levels follow the regular example of other alkaloids, low in the winter and high in the summer and give a wild spectrum of insect resistance. Janthitrems also have a cause to animal health, while less than old standard endophyte.

\subsection{Anticancer Compounds:}

There are some evidences that bioactive compounds produced by endophytes could be substitute approaches for innovation of new drugs, as various natural products of plants, microorganisms and marine sources were identified as anticancer agents [89]. The anticancer properties of several secondary metabolites from have been investigated. Following, are some example of the latent of endophytes on the production of anticancer agents. The diterpenoid "Taxol" $\left(\mathrm{C}_{47} \mathrm{H}_{51} \mathrm{NO}_{14}\right)$ (also known as paclitaxel) have produced more interest and attention than some other novel drug since its discovery probably due to its exclusive mode of action compared to other anticancer agents [90]. This compound impedes with the duplication of cancer cells, sinking or suspending their growth and spreading. FDA (Food and Drug Administration) has agreed Taxol is beneficial for the cure of advanced breast cancer, lungs cancer, refractory ovarian cancer [91]. Taxol was firstly isolated from the bark of tree belonging to taxus family (Taxus brevifolia), its main general resource [92]. The isolation of Taxol-producing endophyte Taxomyces anderanae has provided a different approach to find a cheaper and additional product via microorganism fermentation [130]. Taxol has also been found in a amount of unusual genera of fungal endophytes either related or not to yews, such as Taxodium distichum[93] ;Wollemia nobilis[134]., Phyllosticta spinarum[94]; Bartalinia robillardoides[42] ;Pestalotiopsis terminaliae[42];Botryodiplodia theobromae[95].

Another significant anticancer compound is the alkaloid "Camptothecin" $\left(\mathrm{C}_{20} \mathrm{H}_{16} \mathrm{~N}_{2} \mathrm{O}_{4}\right)$, a powerful antineoplastic agent which was firstly isolated from the wood of Camptotheca acuminate Decaisne (Nyssaceae) in china [96]. Camptothecine and 10-hydroxycamptothecin are two important precursors for the synthesis of the clinically useful anticancer drugs, topotecan, and irinotecan [97]. The anticancer properties of the microbial products camptothecin and two analogues (9-methoxycamptothecin and 10-hydroxycamptothecin) have been already reported. Several reports have described other camptothecin producing endophytes [98]. Since then, endophytes have been included in many studies proposing new approaches drug discovery. Further Promputtha et al $(2007)^{78}$ have isolated Fusarium solani , an endophytic fungus from the inner bark of Camptothca acuminata from Kunming region, china. Moreover this endophyte produced the anti-cancer metabolites- Camptothecin and 9- methoxy camptothecin . "Ergoflavin" $\left(\mathrm{C}_{30} \mathrm{H}_{26} \mathrm{O}_{14}\right)$, a dimeric xanthenes linked in position 2, belongs to the compound class called ergochromes and was described as a new anticancer agent isolated from an endophytic fungi rising on the Mimuscop elengi (Sapotaceae) plant leaves[99]."Secalonic acid D" $\left(\mathrm{C}_{32} \mathrm{H}_{30} \mathrm{O}_{14}\right)$, a mycotoxin also belonging to ergochrome class, is recognized to have powerful anticancer activities. It was isolated from the mangrove endophytic fungus [100]. 
"Lignans" are other kind of anticancer agents originated as secondary metabolites through the shikimate acid pathway [101]. Kelly (2012) ${ }^{102}$ Showed that Lignans have huge structural and biological diversity in cancer chemotherapy. "Phenylpropanoids" have concerned a lot of attention for medicinal use as anticancer, antioxidant, antimicrobial, anti-inflammatory and immunosuppressive properties [100]. Despite the phenylpropanoids belong to the major group of secondary metabolites produced by plant. The endophytic Penicillium brasilianum, found in root bark of Melia azedarch, promoted the biosynthesis of phenylpropanoid amides [101].

Also many other anticancer compounds isolated from endophytes microbes such as "cytoskyrins" [102], "phomoxanthones A and B" [103], "photinides A-F" [104], "rubrofusarin B"[105]. Azadirachta indica is a versatile plant which thrives in the tropics and desert habitats. It is one of the most economically important tree species which is used for insecticidal properties owing to the Azaractin a novel metabolite of importance as a herbal insecticide. It is an important medicinal plant which finds applications in the therapies for its antiseptic properties. This plant has been studied for its endophytic microflora and also for the bioactive natural product [106, 107, 108] Azadirachtin A and B from endophytic fungus of A.indica has been isolated under in vitro axenic conditions [78].

\section{Biotransformation And Endophytes:}

Biotransformation can be defined as the use of biological system to produce chemical changes on compound that are not their natural substrates. The biotransformation process provides a number of advantages over chemical synthesis. Endophytic fungus isolated from the root and shoot of Aphelandra tetragona, transform benzoxazinones, 2-benzoxazolinone (BOA) and 2-hydroxy-1,4-benzoxazin-3-one (HBOA), into different series of compounds [109]. Endophytic fungi use the stereoselective kinetic biotransformation of thioridazine (THD), a phenothiazine neuroleptic drug. Several researchers have also examined the biotransformation of terpenes by endophytes. Several other endophytic microbes were studied for the ability to biotransform natural product like taxoids [110], alkaloids [111], pigment curcumim [112], betulinic, and betulonic acids [113] Application of biotransformation reactions mediated by endophytes appears to be a detoxification effect towards toxic metabolites produce by the host plant. The plants have developed many mechanisms to conquer microbial diseases, as well as the production of a variety of toxic secondary metabolites. The detoxification of these highly bioactive resistance compounds is a significant capability of many endophytes. Benzoxazinones are a unique class of compounds that provide resistance to the pests like bacteria, fungi, and insects . Simanjuntak et al $(2010)^{114}$ studied the microbial endophytes and their potential for improved bioremediation and biotransformation. They have concluded that bacteria and fungi growing in natural ecosystem have been widely used in the production of bioactive product and bioremediation, but potential of endophytes have not been fully exploited. Endophytes are capable of producing biologically active substances related to the secondary metabolites produced by host plants. This might help in the accumulation of many valuable drug compounds such as paclitaxel and camptothecin. Endophytes play a significant role in the degradation of plant litter and organic pollutants that lead to the development of soil fertility.

\section{Endophytes And Molecular Biology:}

The development of molecular biology brings a new prespective to endophyte diversity studies. Many molecular technologies used in endophyte studies such as DNA fingerprinting and sequencing method has the possible to conquer the obstacles in conventional cultivation dependent methods. Molecular identification of sterile mycelium has been done [115,116]. Despite the development of various methods to promote sporulation, molecular methods are useful and required for the identification and understanding of the diversity of endophytic mycelia sterile. Investigation of endophytic fungi from fronds of L.chinensis in Hong Kong has been done [52]. A large number of isolates (16.5\% of total) did not sporulate, remaining as Mycelia sterilia. Molecular identification of isolated endophytic fungus communities such as Ascomycota, Basidiomycota and Zygomycota are reported [119] .They concluded that it is a tough task for mycologists to identify various endophytic fungi into genera or species based on morphological characteristics. Furthermore, it is very time-consuming to make a complete identification. Therefore, DNA sequencing analyses coupled with morphology is being recommended in the investigation of endophyte diversity, particularly for ecology studies. Endophytic strains isolated from Panicum virgatum growing in native tallgrass prairies was identified based on internal transcribed spacer (ITS) sequence analyses [120]. These authors [120] found that a wide range of fungal species from at least 18 different taxonomic orders existed as endophytes in Swithgrass plants and that the fungal communities from shoot tissue had considerably superior species diversity than those from root tissues. Kirchhof et al (1997) ${ }^{121}$ studied the physiological and molecular analysis of endophytic diazotrophic bacteria in grass plants. They have investigated endophytic bacteria by PCR fingerprinting using 
oligonucleotides directed to sequences which are derived from LINEs (Long Interspersed Elements) and are supposedly conserved in all cells. And observed isolates exhibit similar banding pattern with only few bands varying in their molecular weight. This can be found for several isolates of Pennisetum purpureum,Herbaspirillum seropedicae,) as well as Miscanthus sinensis and Miscanthus saccharifloru., Morakotkarn et al (2007) ${ }^{122}$ concluded that endophytic fungi of $18 \mathrm{~S}$ and $28 \mathrm{~S}$ genes may be employed in the identification of fungi at high taxonomic levels by ITS sequence data. DGGE (Denaturing gradient gel electrophoresis ) techniques, which are capable of separating closely related sequences by their differential mobilities in a gradient of denaturants, have recently been successfully applied to document endophytic fungal communities by excising and sequencing bands, thereby obtaining taxonomic information for members of the community via database searches and phylogenetic analysis [123]. Ding et al (2009) ${ }^{124}$ recovered 14 OTUs from Magnolia liliifera using DGGE coupled with sequencing, which were totally different from the morpho species recovered by the traditional cultivation method. Pyrosequencing is the recently developed, high-throughput sequencing method which is enables metagenomic and metagenetic analyses and provides an influential option to molecular studies of fungal community in natural environments. This technique has been successfully employed in the study of fungal diversity in natural environments, such as clinical fungi [125], phyllosphere fungi [126], woodinhabiting fungi [127] and soil fungi [69].

\section{Applications}

Endophytes can confer host resistance to biotic and abiotic stresses; modify the host physiological characteristics, induced by the plant hormone and synthesize other biological compounds [128] which are of great potential application in controlling phytopathogen and promoting the plant growth [129].

11.1.Biological control: Plant diseases and insect pests have been one important factors restraining agriculture development and it have already caused a great loss to agriculture products. Although chemical pesticides can decrease the pests and the hazards of pathogen, it threatens the environment and the health of human beings, which also induce the disorder of ecological environment. Entomopathogenic microorganisms or individuals that reduce the other pathogenic microorganisms to plants used to control diseases and pests are a substitute to reduce the use of chemical products in agriculture [128].The endophytic bacteria and rhizobacteria in the disease-free banana seedlings, reduces the infection of banana bunchy top virus. to $33.3 \%$ with $60 \%$ reduction over control, hence improve the resistance of the plant to disease [54].

11.2. Plant Growth promotion: Endophytes can produce lots of metabolites such as indole acetic acid (IAA), indole acetonitrile, gibberlin and cytokine, can play important role in promoting root elongation and plant growth [89]. Zhang isolated 5 endophytic fungi from medicinal plants and 5 kinds of phytohormone were extracted from the fungal fermented liquid and mycelia, which were proved to promote orchid growth [111]. Some endophyte species produce antibiotic substances which restrain pathogen growth to reduce its damage to plant through competition nutrition and space with pathogen or directly producing antagonist material $[118 ; 132 ; 133]$. On the other hands, endophyte can enhance the host ability to absorb nutrients to promote plant growth [134].

11.3. Other applications: Endophytic fungi in the marine plant can help saprophytic bacteria to decomposition again plant in the salt marshes [27]. Endophyte can enhance the plant resistance to drought. Endophyte is also a molecular tool to act as gene carrier. Exogeneous genes can be transferred to endophytes; and the exogeneous gene could be expressed in the plants after it were colonized the endophyte to protect The other beneficial effects of endophytes to plants include acquiring nutrients, via iron chelation, increased drought resistance, nitrogen fixation, thermal protection phosphate solubilization, endurance under osmotic stress. A particular bacterium may affect plant growth and development using one or more of these mechanisms and may use different ones at various times during the life cycle of the plant. The endophytic bacteria have a huge amount of relevance that improves agricultural production. Endophytic bacteria have improved wheat growth through production of phytohormones; increased cotton disease resistance; increased rice production by increasing mineral availability; fix nitrogen in wheat and rice; decrease propensity to frost damage; contribute to increase potato tuber formation and corn pest management under heat stress conditions. 


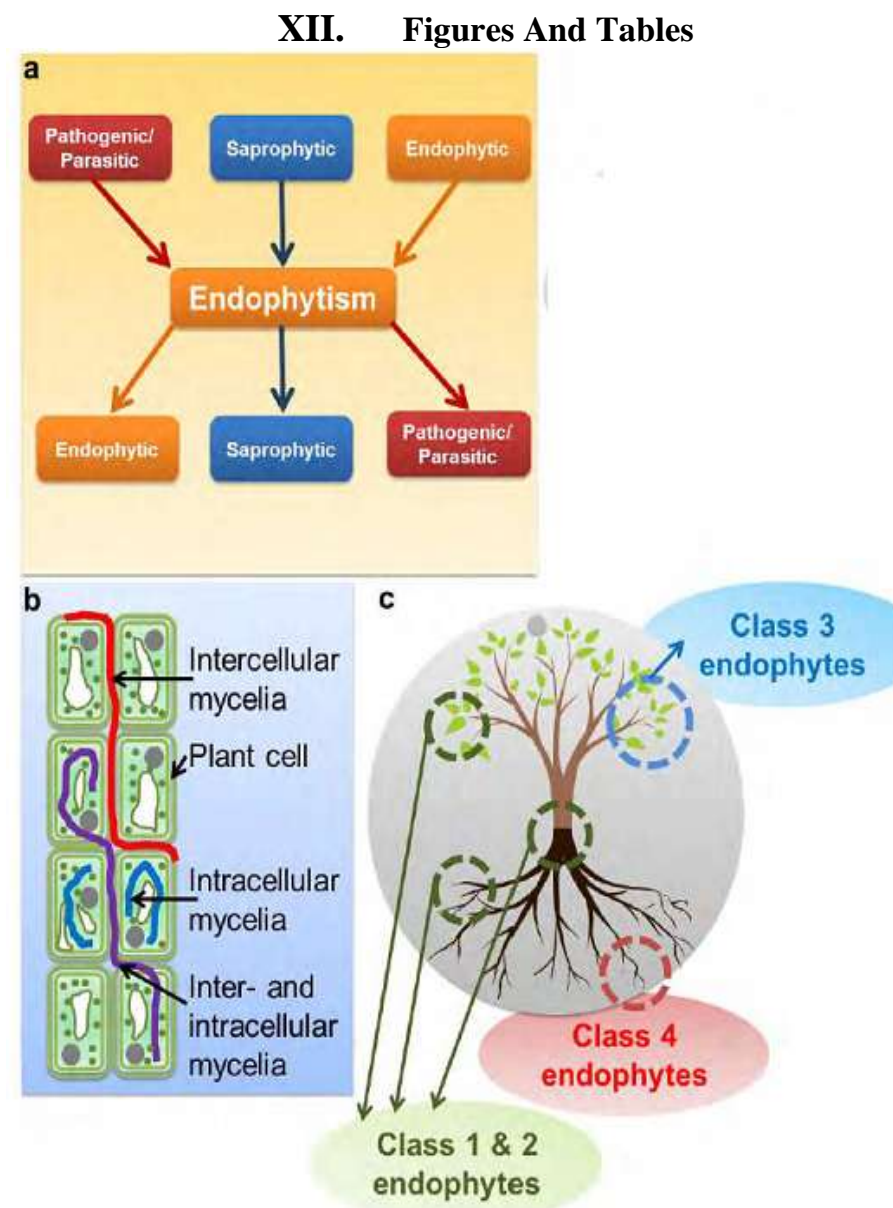

Figure 1- Diagrammatic representation of endophytic fungal association with their host plants. (a) Possible life histories of endophytic fungi pre and post "endophytism" (b) Different localization patterns of fungal endophytes within plant tissues .(c) Localization of different classes of endophytes [113]. An artistic rendition according to [52].

[Source: Souvik Kusari and Michael Spiteller (2012), Metabolomics of endophytic fungi producing plant secondary metabolites: Progress, challenges and opportunities In Metaboloics Eds Ute Roessner, Pub InTech, Rijeka, Croatia : pp 241-266. www.intechopen.com ]

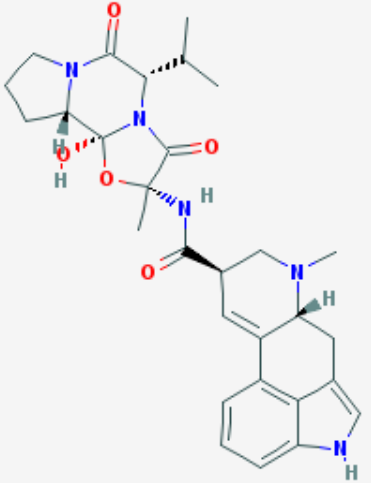

Ergovaline

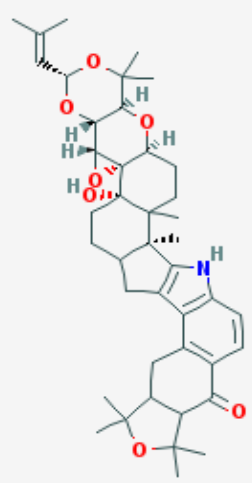

LolitremB 


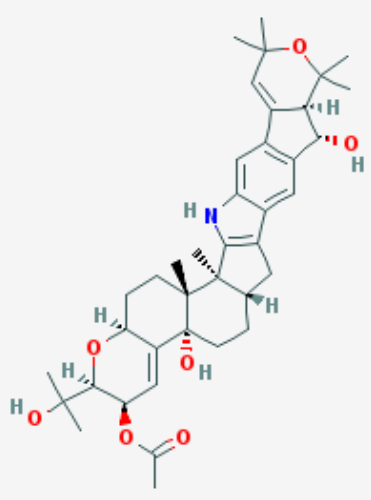

Janthitrems

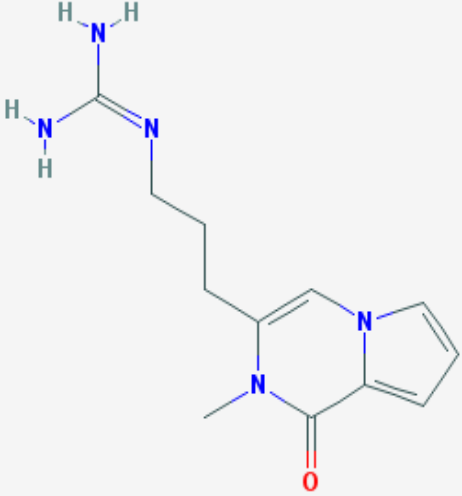

Peramine

Figure 2- Structure of chemicals produced by endophytes

[Source: Structure of endophytes obtained from NCBI Pub-chem database.]

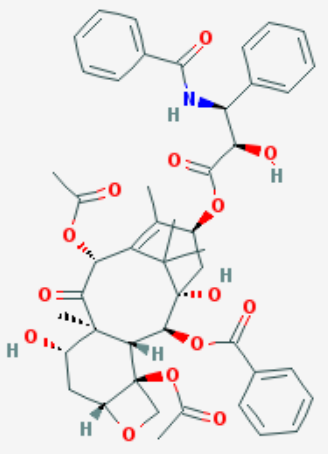

Camptothecin

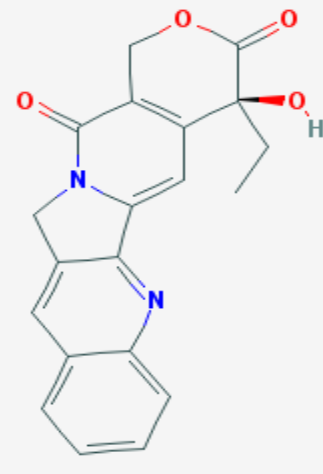

Taxol

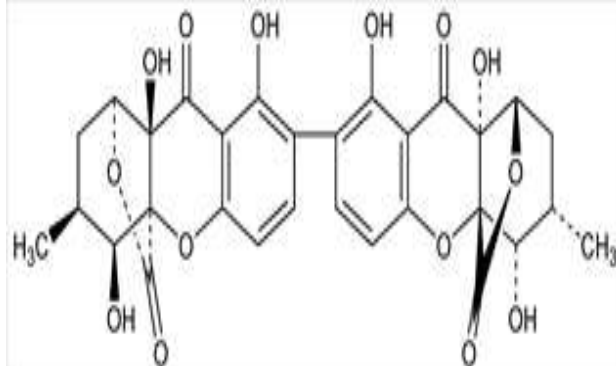

Ergoflavin

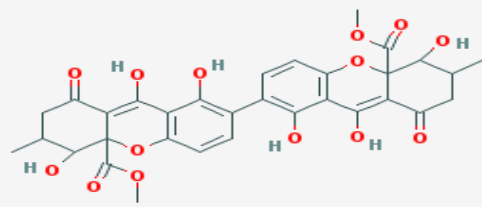

Secalonic acid D

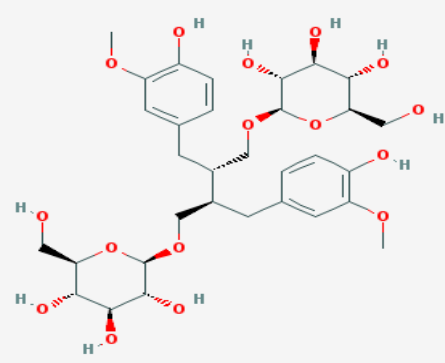

Lignans<smiles>COc1cc(C[C@H]2c3cc4c(cc3[C@@H](O)[C@@H]3COC(=O)[C@@H]32)OCO4)cc(OC)c1OC</smiles>

C10874

Figure 3- Somechemicals produced by endophytics microorganisms. [ Source: Structures obtained from NCBI Pub-chem database] 
Table 1Example of different chemicals produced by endophytes:

\begin{tabular}{|l|l|l|l|l|}
\hline Endophytes & Peramine & LolitremB & Ergovaline & Janthitrems \\
\hline AR1 & Produced & Not produced & Not produced & Not produced \\
\hline NEA2 & Produced & Very low & Low & Not produced \\
\hline Endo5 & Produced & Not produced & Low & Not produced \\
\hline AR37 & Not Produced & Not produced & Not produced & Produced \\
\hline Standard & Produced & Very high & High & Not produced \\
\hline
\end{tabular}

Table 2 Metabolites produced by entophytes

\begin{tabular}{|c|c|c|c|c|}
\hline Species & Host & Metabolite & $\begin{array}{l}\text { Biological } \\
\text { activity }\end{array}$ & References \\
\hline $\begin{array}{l}\text { Taxomyces } \\
\text { anderanae }\end{array}$ & $\begin{array}{l}\text { Taxus } \\
\text { brevifolia }\end{array}$ & Taxol/ Paclitaxol & Anticancer & {$[130]$} \\
\hline $\begin{array}{l}\text { Taxomyces } \\
\text { anderanae }\end{array}$ & $\begin{array}{l}\text { Taxus } \\
\text { brevifolia }\end{array}$ & Camptothecin & Antineoplastic & {$[134,135,125]$} \\
\hline $\begin{array}{l}\text { Taxomyces } \\
\text { anderanae }\end{array}$ & $\begin{array}{l}\text { Taxus } \\
\text { brevifolia }\end{array}$ & $\begin{array}{l}\text { Podophyllotoxin } \\
\text { deoxypohophyllotoxin }\end{array}$ & Anticancer & {$[134,135]$} \\
\hline $\begin{array}{l}\text { Taxomyces } \\
\text { anderanae }\end{array}$ & $\begin{array}{l}\text { Taxus } \\
\text { brevifolia }\end{array}$ & Azadirachtin A \&B & $\begin{array}{l}\text { Natural } \\
\text { insecticide }\end{array}$ & [52] \\
\hline $\begin{array}{l}\text { Fusarium } \\
\text { Solani }\end{array}$ & Taxus baccata & $\begin{array}{ll}\text { Mixed } & \text { volatile } \\
\text { compound } & \end{array}$ & Antimicrobial & {$[12]$} \\
\hline $\begin{array}{l}\text { Fusarium } \\
\text { oxysporium }\end{array}$ & $\begin{array}{l}\text { Juniperus } \\
\text { recurva. }\end{array}$ & Podophyllotoxin & $\begin{array}{l}\text { Anticancer } / \\
\text { Antimicrobial }\end{array}$ & {$[136]$} \\
\hline $\begin{array}{l}\text { Gliociadium } \\
\text { spp }\end{array}$ & $\begin{array}{l}\text { Eucryphia } \\
\text { cardifolia }\end{array}$ & Volatile compound & Antimicrobial & [137] \\
\hline $\begin{array}{l}\text { Pestalotiopsis } \\
\text { guepinii }\end{array}$ & $\begin{array}{l}\text { Wallemia } \\
\text { nobilis }\end{array}$ & Taxol & Anticancer & [33] \\
\hline Taxus mairei & $\begin{array}{l}\text { Tubrallaria spp } \\
\text { / Strain TF5 }\end{array}$ & Taxol & Anticancer & [67] \\
\hline $\begin{array}{l}\text { Fusarium } \\
\text { solani }\end{array}$ & Taxus baccata & Azaphilone & Anticancer & [93] \\
\hline $\begin{array}{l}\text { Fusarium } \\
\text { oxysporium }\end{array}$ & $\begin{array}{l}\text { Juniperus } \\
\text { Recurva }\end{array}$ & Podophyllotoxin & Anticancer & [136] \\
\hline $\begin{array}{l}\text { Pseudomonas } \\
\text { viridiava }\end{array}$ & Grass & Ecomycins $\mathrm{B}$ and $\mathrm{C}$ & Antimicrobial & {$[138]$} \\
\hline $\begin{array}{l}\text { Serratia } \\
\text { marcescens }\end{array}$ & $\begin{array}{l}\text { Rhyncholacis } \\
\text { penicillata }\end{array}$ & Oocydin A & Antifungal & [6] \\
\hline Streptomycessp. & Monstera $s p$. & Coronamycin & $\begin{array}{l}\text { Antimalarial } \\
\text { antifunga }\end{array}$ & [139] \\
\hline $\begin{array}{l}\text { StreptomycesNR } \\
R L 30566\end{array}$ & $\begin{array}{l}\text { Grevillea } \\
\text { pteridifolia }\end{array}$ & Kakadumycins & Antibiotic & [140] \\
\hline Cytonaema $s p$ & Quercussp. 103 & $\begin{array}{l}\text { Cytonic acids A and } \\
\text { D }\end{array}$ & Antiviral & {$[118]$} \\
\hline $\begin{array}{l}\text { Eupenicillium } \\
\text { parvum }\end{array}$ & $\begin{array}{l}\text { Azadirachta } \\
\text { indica }\end{array}$ & Azadirachtin & Pesticide & {$[5]$} \\
\hline $\begin{array}{l}\text { Entrophospora } \\
\text { infrequens }\end{array}$ & $\begin{array}{l}\text { Nothapodytes } \\
\text { foetida }\end{array}$ & Camptothecin & Antineoplastic & {$[134]$} \\
\hline
\end{tabular}

Table 3 List of few patents on endophytes:

\begin{tabular}{|l|l|l|}
\hline Title & Patents No & Inventors \\
\hline $\begin{array}{l}\text { A naphthalene producing endophytic fungus } \\
\text { M.Vitigenus }\end{array}$ & US 7,267,975 & 141 \\
\hline $\begin{array}{l}\text { Endophytic streptomycetes from higher } \\
\text { plants with biological activity }\end{array}$ & US 7,259,004 & 142 \\
$\begin{array}{l}\text { Taxol from T.andrenae and other } \\
\text { endophytes }\end{array}$ & US5,861,302,5322,779,5,908,759,5,916, & 143 \\
\hline \\
Use of endophytic fungi to treat plant & US 7,232,565,B2 & 144 \\
\hline
\end{tabular}


Current Understanding Of Endophytes: Their Relevance, Importance, And Industrial Potentials

\begin{tabular}{|l|l|l|}
\hline Grass endophytes & US 2011/0262401A1 & 145 \\
\hline $\begin{array}{l}\text { Endophyte enhanced seedling with increase } \\
\text { pest tolerance }\end{array}$ & US 2011/0173727 & 146 \\
\hline $\begin{array}{l}\text { Grass based avain deterrent } \\
\text { Grass fungal endophytes and uses thereof }\end{array}$ & US2012/0144533 & 147 \\
\hline $\begin{array}{l}\text { Antifungal metabolites from fungal } \\
\text { endophytes of pinus strobus }\end{array}$ & US2012/0198590 & 148 \\
\hline $\begin{array}{l}\text { Endphytes and related methods } \\
\text { Tall fescue endophytes }\end{array}$ & US2013/0104263 & 149 \\
\hline $\begin{array}{l}\text { Improvement in grass endophytes } \\
\text { Method for protecting grass using an } \\
\text { endophyte }\end{array}$ & EP2636302 A1 & 150 \\
\hline $\begin{array}{l}\text { Ryegrass endophyte } \\
\text { WO11170A }\end{array}$ & 151 \\
\hline
\end{tabular}

\section{Conclusion}

Endophytes have been adopted by plants and have remained unnoticed by taxonomist till beginning of last century. However, they have not been extensively studied to enhance our understanding of their influence on plant physiology, biochemistry \& adaptation to varied habitats. They are also rich source of a range of bioactive molecules within a range of applications in medicine, agriculture, and industry. The key questions which need answers are i) whether it is possible to exploit the endophytes for various agronomic adaptations of agricultural plants to enhance productivity? ii) Is it possible to exploit their specific traits for plant improvement and secondary metabolite production? The discoveries of a range of various molecules produced by the endophytes hold great prospect in the production of chemicals for drug. Many patents are held on such recent outcome ("Table 3").One of the bottle necks in the production of the secondary metabolite from the isolated endophyte cultured auxenically is its inability to produce the desired metabolite in a sustainable and highly efficient manner. At times it is also not possible to produce the desired compounds because some portion of the pathway is expressed in the endophytes and some other is contributed by the host plants. We need to also find out about the signaling mechanisms and also movement of metabolites from the fungus to the host tissue and vice versa coupled to biotransformation abilities. With the above mentioned information being unfolded, it is expected that the future years will bring in greater insights into understanding of endophytes through basic research and open up a range of application as discussed in this review.

\section{Acknowledgment}

Authors(SAT ,DR ,SK AND RAG) are Thankful to Vice Chairman Dr. Premachandra Sagar for his keen support and encouragement. Further the financial assistance by Dayananda Sagar Institutions is gratefully acknowledged. RAG wishes to thank Department of Science and Technology, Government of India for financial support through competitive grant.

\section{References}

[1] Leuchtmann, Systematics, distribution, and host specificity of grass endophytes J. Nat Toxins, 1, 1992,150-62.

[2] Hallmann, J., Quadt-Hallmann, A., Mahaffee, W.F., and Kloepper, J.W, Bacterial endophytes in agricultural crops. Can. J. Microbiol. 43, 1997,895-914.

[3] Freeman, E.M., Philos., Trans., R. Soc., Lond., [Biol]. 1904 ,196. 1.

[4] Huang, W.Y., Yi, Zhong, Cai., Kevin, D.H., Harold, C., and Mei, S, Endophytic fungi from Nerium oleander L (Apocynaceae): main Constituents and antioxidant activity J. World Journal of Microbiology and Biotechnology. 23,2007,1253-1263.

[5] Kusari, S., and Spiteller, M, Metabolomics of endophytic fungi producing associated plant secondary metabolites: progress, challenges and opportunities. In Metabolomics, U. Roessner, ed. (Rijeka, Croatia: InTech) 2012,241-266.

[6] Strobel, G., Daisy, B., Castillo, U., and Harper, J, "Natural products from endophytic, microorganisms" Journal of Natural Products. 67, 2004, 257-268.

[7] Strobel, G, ."Endophytes as sources of bioactive products," Microbes and Infection. 5, $2003,535-544$. 
[8] Owen, L., and Hundley, N, "Endophytes - the chemical synthesizers inside plants," Science Progress.87, 2004, 79-99.

[9] Tan, R.X., and Zou, W.X, "Endophytes: a rich source of functional metabolites," Natural Product Reports.18, 2001, 448459.

[10] Wang, Y., H, Lie Paul, The Summarize About Recent Research Process on Gramineae Endophyte Symbiosis J(In Chinese). Biotechnology Bulletin. 3, 2008, 33-38.

[11] Bacon, C.W., and White, J.F,. Microbial Endophytes (New York: Marcel Deker Inc. 2000

[12] Strobel, G., Daisy, B., Castillo, U., \& Harper, J, Natural products from endophytic microorganisms. J Nat Prod. 67, 2004,257-268

[13] Kumar, S., and A, Sagar, Microbial associates of Hippohae rhamnoides (Seabuckthorn) Plant Pathol.J. 6, 2007,299-305.

[14] Petrini, O., Andrews, J.H., and Hirano, S.S, Fungal endophytes of tree leaves. Microbial Ecology of the Leaves. NewYork Springer Verlag. 1991,179-197.

[15] Sikora, R.A.K., Schäfer, A.A., Dababat, Modes of action associated with microbially induced in planta suppression of plant-parasitic nematodes J. Australasian Plant Pathology. 36, 2007,124-134.

[16] Li, W.K.,. Endophytes and Natural Medicines J. Chinese Journal of Natural Medicines (InChinese).3, 2005,193-199.

[17] Backman, P.A., and R.A, Sikora, Endophytes: An emerging tool for biological control J.Biological Control. 46, 2008, 1-3.

[18] Dreyfuss, M., \& Chapela, I, Potential of fungi in the discovery of novel, low-molecular weight pharmaceuticals. The Discovery of Natural Products with Therapeutic Potential (Gullo VP, ed).6, 1994, 49-80.

[19] Bacon, C.W., Porter, J.K., Robbins, J.D., and Luttrell, E.S,..Epichloe typhina from toxic tall fescue grasses. Appl. Environ. Microbiol. 34, 1977, 576-581.

[20] Schardl, C.L., Leuchtmann, A., and Spiering, M.J, Symbioses of grasses with seedborne fungal endophytes. Annu. Rev. Plant Biol. 55, 2004,315-340.

[21] Sathe, V., \& Raghukumar, S, Fungi and their biomass in detritus of the seagrass Thalassia hemprichii (Ehrenberg) Ascherson. Botanica Marina. 34, 1999, 271-277.

[22] Senthilkumar, S., Krishnamurthy, K.V., Bitto, S.J., and Arockiasamy, D.I., Curr Sci. ; 79, $2000,1527-1528$.

[23] Arnold, A.E, Understanding the diversity of foliar endophytic fungi: progress, challenges, and frontiers. Fungal Biology Reviews. 21, 2007,51-66.

[24] Schulz, B., Boyle C, The endophytic continuum: Review Mycol Research. 109, 2005,661-98.

[25] Kharwar, R.N., Mishra, A., Gond, S.K., et al, Anticancer compounds derived from fungal endophytes: their importance and future challenges. Nat. Prod. Rep.28, 2011,1208-1228.

[26] Clay, K., Schardl, C.L, Evolutionary origins and ecological consequences of endophyte symbiosis with grasses. American Naturalist. 160, 2002,S99-S127.

[27] Waller, B., Aehatz, H.J., Baltruschat, K., et al, Proceeding of Natural Academic of Science.102, 2005,13386-13391.

[28] Redman, R.S., Sheehan, K.B., Stout, R.G., et al, Thermotolerance generated by plant/fungal symbiosis. Science.298, 2002, 1581 .

[29] Stoyke, G., and Currah, R.S, Endophytic fungi from the mycorrhizae of alpine ericoid plants. Can J Bot. 69, 1991,347352.

[30] Suryanarayanan, T.S., Kumaresan, V., A simple method for storing and transporting Fungal Cultures. Mycologist.12, 1998, 173.

[31] Stierle, A., Strobel, GA., and Stierle, D, Taxol and taxane production by Taxomyces andreanae, an endophytic fungus of Pacific yew. Science. 260, 1993, 214-216.

[32] Osterhage, C.,Höller, U., König, G.M., and Wright, A.D, .Ascosalipyrrolidinone A, an Antimicrobial Alkaloid, from the Obligate Marine Fungus Ascochyta salicorniae J. The Journal of Organic Chemistry.65, 2000, 6412-6417.

[33] Strobel, G.A., Hess, W.M., Li, J.Y, "Pestalotiopsis guepinii,a taxol-producing endophyte of the wollemi pine, Wollemia nobilis," Australian Journal of Botany. 45, 1997, 1073-1082.

[34] Petrini., Ecological and Physiological aspects of host specificity in endophytic fungi. In EndophyticFungi in Grasses and Woody Plants. American Phytopathological Society Press: St Paul MN. $1996,87-100$.

[35] Schardl, C.L, Epicholë festucae and related mutualistic symbionts of grasses. Fung Gene Biol. ; 33, $2001,69-82$.

[36] White, J.F., Reddy, P.V., Bacon, C.W, Biotrophic endophytes of grasses: a systemic appraisal. In: Bacon CW, White JF, Editors, Microbial Endophytes. Marcel Dekker, New York; 2000,49-62.

[37] Bultman, T.L., Murphy, J.C, Do fungal endophytes mediate wound-induced resistance Microbial Endophytes, Marcel Dekker, New York. $2000,421-52$.

[38] Pan, J.J., \& Clay, K, Epichloe glyceriae infection affects carbon translocation in the clonal grass Glyceria striata New Phytologis. 164, 2004,467-475.

[39] Sinclair, J.B., Cerkauskas, R.F, Latent infection vs. endophytic colonization by fungi. In: Redlin, S.C., Carris LM., editors. Endophytic fungi in grasses and woody plants: systematics, ecology, and evolution. St. Paul (MN): APS Press,1996,3-29.

[40] Rodriguez, R.J., White, J.F., Arnold, A.E., Redman, R.S, Fungal endophytes: diversity and functional roles. New Phytologist. ; 182, 2009, 314-330.

[41] Schulz, B., Römmert, A.K., Dammann, U., et al, The endophyte-host interaction: a balanced antagonism? Mycological Research. 103, 1999., 1275-1283

[42] Wille, P.A., Aeschbacher, R.A., Boller, T, Distribution of fungal endophyte genotypes in doubly infected host grasses. The Plant Journal. 18, 1999, 349-358.

[43] White, J.F., Sullivan, R., Balady, G., Gianfagna, et al, A fungal endosymbiont of the grass Bromus setifolius: distribution in some Andean populations, identification, and examination of beneficial properties. Symbiosis. 31, 2001, $241-257$.

[44] Tadych, M., Bergen, M., Dugan, F.M., et al, Evaluation of the potential role of water in the spread of conidia of the Neotyphodium endophyte of Poa ampla. Mycological Research. ; 111, 2007, 466-472.

[45] Johnson, N.C., Graham, J.H., Smith, F.A, Functioning of mycorrhizal associations along the mutualism-parasitism continuum. New Phytologist. 135, 1997, 575-586.

[46] Weber, R.S., Stenger, E., Meffert, A., Hahn M, Brefeldin A production by Phoma medicaginis in dead pre-colonized plant tissue : a strategy for habitat conquest? Mycological Research. ; 108, 2004, 662-671.

[47] Rosenblueth, M., and Martinez, Romero, E, Rhizobium etli maize populations and their competitiveness for root colonization. Arch. Microbiol. 181, 2004,337-344.

[48] Campanile, G., Ruscelli, A., Luisi, N, Antagonistic activity of endophytic fungi towards Diplodia corticola assessed by in vitro and in planta tests. European Journal of Plant Pathology. ; 117, 2007, 237-246.

[49] Idnurm, A., Howlett, B.L, Pathogenicity genes of phytopathogenic fungi. Molecular Plant Pathology. ; 2,2001 ,241-255. 
[50] Arnold, A.E., and Herre, E.A, Canopy cover and leaf age affect colonization by tropical endophytes: ecological pattern and process in Theobromae cacao (Malvaceae). Mycologia. ; 95 ,2003,,388-398.

[51] Mandyam, K., Jumpponen, A, Seeking the elusive function of the root-colonising dark septate endophyte. Studies in Mycology. ; 53, 2005 , 173-189.

[52] Kusari, S., Kosuth, J., Cellarova, E., Spiteller, M, Survival-strategies of endophytic Fusarium solani against indigenous camptothecin biosynthesis. Fungal Ecol. ; 4, $2011,219-223$.

[53] Sturz, A., and Kimpinski, J, Endoroot bacteria derived from marigolds (Tagetes spp.) can decrease soil population densities of root lesion nematodes in the potato root zone. Plant Soil. ; 262, 2004,241-249.

[54] Cho, K., Hong, SY., Lee, SM., et al Endophytic Bacterial Communities in Ginseng and their Antifungal Activity against Pathogens. J. Microbial Ecology; 54, 2007,341-351.

[55] Nakasone, K.K., Peterson, S.W., and Jong, S, Preservation and distribution of fungal cultures. In Biodiversiy of fungi Inventory and monitoring methods. Edited by, G.M, Muller., G.F, Bills., and M.S, Foster., Elsevier Academic Press, USA. 2004, 37-47.

[56] Li, J.H., En, Tao, Wang., Wen., et al, Genetic diversity and potential for promotion of plant growth detected in nodule endophytic bacteria of soybean grown in Heilongjiang province of China J. Soil Biology and Biochemistry. 40, 2008,238246.

[57] Pullen, C., Schmitz, P., Meurer, K., et al, New and bioactive compounds from Streptomyces strains residing in the wood of Celastraceae J.Planta,216, $2002,162-167$.

[58] Gaiero, J.R., McCall, C.A., Thompson, K.A., et al, Inside the root microbiome: bacterial root endophytes and plant growth promotion. Am. J. Bot. $100,2013,1738-1750$.

[59] Lan, R., Reeves, P.R., Octavia, S, Population structure, origins and evolution of major Salmonella enterica clones. Infect. Genet. Evol.9, 2009, 996-1005.

[60] Holden, N., Pritchard, L., Toth, L, Colonization outwith the colon: plants as analternative environmental reservoir for human pathogenic enterobacteria. FEMS Microbiol. Rev.33, 2009, 689-703.

[61] Adam Schikora1., Ana V., Garcia2., and Heribert Hirt, Plants as alternative hosts for Salmonella. Trends in Plant Science; $17,2012,5$.

[62] Cooley, M.B., Miller, W.G., and Mandrell, R.E, Colonization of Arabidopsis thaliana with Salmonella enterica and enterohemorrhagicEscherichia coli $\mathrm{O} 157: \mathrm{H} 7$ and competition by Enterobacter asburiae.Appl. Environ. Microbiol. 69, 2003,4915-4926.

[63] Hasegawa, S., Meguro, A., Shimizu, M., et al, Endophytic actinomycetes and their interactions with host plants. Actinomycetologica. 20, 2006,72-81.

[64] Stoyke, G., and Currah, R.S, Endophytic fungi from the mycorrhizae of alpine ericoid plants. Can J Bot. 69, 1991, 347352 .

[65] Bacon, C.W, Procedure for Isolating the Endophyte from Tall Fescue and Screening Isolates for Ergot Alkaloids Appl. and Environment Microbiol. 54, 1988 , 2615-2618.

[66] Santhosh, W.G., Royston, M., Shashi, K.N., Leo, S, Isolation of endophytic fungi from Coscinium fenestratum -a red listed endangered medicinal plant Eurasia. J. Biosci. 5, 2011, 48-53.

[67] Wang, Y., Guo, L.D., and Hyde, K.D,Taxonomic placement of sterile morphotypes of endophytic fungi from Pinus tabulaeformis (Pinaceae) in northeast China based on rDNA sequences. Fungal Divers.20,2005, 235-260.

[68] Guimarães, D.O., Borges, W.S., Vieira, N.J., et al, Diketopiperazines produced by endophytic fungi found in association with two Asteraceae species.Phytochemistry. 71, 2010,1423-1429.

[69] Cheplick, G.P, Effect of simulated acid rain on the mutualism between tall fescue (Festuca arundinacea) and an endophytic fungus (Acrenzo)iium coenophialuin). Int. J. Plant Sci. 154, 1993,134-143.

[70] Sherf, A.F, A method for maintaining Phytomonas sepedonica in culture for long periods without transfer Phytopathol. 33, 1943, 330-332.

[71] Buell, C.B., Weston, W.H, Application of the mineral oil conservation method to maintaining collections of fungus cultures. Am J Bot. 34, 194. 555-561.

[72] Perrin, P.W, Long-term storage of cultures of wood-inhabiting fungi under mineral oil. Mycologia. 71, 1979, 865-869.

[73] Borba, C.M., and Rodrigues, K.F, Viability and sporulating capability of Coelomycetes preserved under a range of different storage regimes. Rev. Iberoam. Micol. 17, 2000,142-145.

[74] Johnson., and Martin, Survival of wood inhabiting fungi stored for 10 Years in water and under oil. Can. J. Microbiol.38, 1992,861-864.

[75] de Matos Nogueira, E, Vinagre, F, Masuda, HP, et al, Expression of sugarcane genes induced by inoculation with Gluconacetobacter diazotrophicus and Herbaspirillum rubrisubalbicans. Genet. Mol. Biol. 24, 2001,199-206.

[76] Tejesvi, M.V., Kini, K.R., Prakash, H.S., et al, Genetic diversity and antifungal activity of species of Pestalotiopis isolated as endophytes from medicinal plants. Fungal Divers.24, 2007,37-54.

[77] Barnett, H.L., Hunter, B.B Illustrated genera of imperfect fungi. ASP Press,St.Paul, Minnesota,USA. 1998.

[78] Promputtha, I., Jeewon, R., Lumyong, S., et al, Phylogenetic evaluation of whether endophytes become saprotrops at host senescence. Microbial. Ecol. 53, 2007,579-590.

[79] Tiago de Souza Leite., Andreia Cnossen-Fassoni., Olinto Liparini Pereira., et al, A novel and highly diverse fungal endophytes in soybean revealed by consortium of two different techniques. ; http://link.springer.com/article/10.1007/s122752013-2356-x.

[80] Kuklinsky., Sobral, J., Araujo, W.L., et al, Isolation and characterization of soybean -associated bacteria and their potential for growth promotion. Environ. Microbiol. ; 6, 2004 ,1244-1251.

[81] Latch.G, C.M., Christensen, M.J., Samuels, G.J, Five endophytes of Lolium and Festuca in New Zealand. Mycotaxon.20, 1984, 535-550.

[82] Bakker, P.A., H.M., Ran, L.X., Pieterse, et al, Understanding the involvement of rhizobacteria-mediated induction of systemic resistance in biocontrol of plant diseases. Can. J. Plant Pathol. 25, 2003,5-9.

[83] Breen, J.P, Acremonium endophyte interactions with enhanced plant resistance to insects. Annual Review of Entomology. 39, 1994, 401-423.

[84] Lugtenberg, B.J.J., L, Dekkers., and G.V, Bloemberg., Molecular determinants of rhizosphere colonization by Pseudomonas. Annu. Rev. Phytopathol. 19, 2003, 461-490.

[85] Van, Loon, L.C., Bakker, P.A., \& Pieterse, C.M.J, Systemic resistance induced by rhizosphere bacteria. Ann Rev Phyto. $36,1998,453-483$. 
[86] Rodriguez, R.J., J, Henson., E, Van, et al, Stress tolerance in plants via habitat-adapted symbiosis. ISME Journal. 2, 2008.,404-416.

[87] Rodriguez, R.J., C, Woodward., and R.S, Redman, Adaptation and survival of plants in high stress habitats via fungal endophyte conferred stress tolerance, In J. Seckbach and M. Grube ( eds), Symbioses and Stress Cellular origin, life in extreme habitats and astrobiology,Springer, Dordrecht, Netherlands.17, 2010,463-476

[88] Gunatilaka, A.A.L, Natural products from plant-associated microorganisms: Distribution, structural diversity, bioactivity and implication of their occurrence. J Nat Prod. 69, 2006,509-526.

[89] Fill, D.A.Silva., and Rodrigues-Fo, "Biosynthesis of phenylpropanoid amides by an endophytic penicillium brasilianum found in root bark of Melia azedarach," Journal of Microbiology and Biotechnology. 20, 2010, 622-629.

[90] Fir'akov'a., 'Sturd'ikov'a., and M'u'ckov'a., "Bioactive secondary metabolites produced by microorganisms associated with plants," Biologia. 62, 2007, 251-257.

[91] Cremasco, M.A., Hritzko, B.J., and Linda, Wang, N.H, "Experimental purification of paclitaxel from a complex mixture of taxanes using a simulated moving bed," Brazilian Journal of Chemical Engineering. 26, 2009,207-218.

[92] Wani, M.C., Taylor, H.L., Wall, M., et al, "Plant antitumor agents. VI. The isolation and structure of taxol, a novel antileukemic and antitumor agent from Taxus brevifolia," Journal of the American Chemical Society. 93, 197, $2325-2327$.

[93] Li., Strobel., Sidhu., Hess., and Ford, "Endophytic taxol-producing fungi from bald cypress Taxodium distichum," Microbiology.142, 1996,2223-2226.

[94] Kumaran .R., Muthumary. J and Hur. B.K, "Production of taxol from Phyllosticta spinarum, an endophytic fungus of Cupressus sp," Engineering in Life Sciences. 8, 2008,438-446.

[95] Pandi.M., Manikandan. R., and Muthumary. J, "Anticancer activity of fungal taxol derived from Botryodiplodia theobromae Pat, an endophytic fungus, against 7, 12 dimethyl benz(a)anthracene (DMBA)-induced mammary gland carcinogenesis in Sprague dawley rats," Biomedicine and Pharmacotherapy.64, 2010,48-53.

[96] Wall, M.E., Wani, M.C, Cook, C.E., et al, "Plant antitumor agents I. The isolation and structure of camptothecin, a novel alkaloidal leukemia and tumor inhibitor from Camptotheca acuminata," Journal of the American Chemical Society. 88 , 1966, 3888-3890.

[97] Uma, S.R., Ramesha, B.T., Ravikanth, G., Rajesh, et al, "Chemical profiling of N. nimmoniana for camptothecin, an important anticancer alkaloid: towards the development of a sustainable production system," in Bioactive Molecules and Medicinal Plants, K G. Ramawat and J. Merillion, Eds 2008,.198-210.

[98] Shweta, S., Zuehlke. S., Ramesha, B.T, "Endophytic fungal strains of Fusarium solani, from Apodytes dimidiate E. Mey. ex Arn (Icacinaceae) produce camptothecin, 10- hydroxycamptothecin and 9-methoxycamptothecin," Phytochemistry. 71, 2010, 117-122.

[99] Deshmukh, S.K., Mishra, P.D., Kulkarni-Almeida. et al, "Anti-inflammatory and anticancer activity of ergoflavin isolated from an endophytic fungus," Chemistry and Biodiversity. 6, 2009,784-789.

[100] Zhang, J.Y., Tao, L.Y., Liang, Y.J, "Secalonic acid D induced leukemia cell apoptosis and cell cycle arrest of G1 with involvement of GSK-3 $\beta / \beta$-catenin/c-Myc pathway," Cell Cycle. 8, 2009, 2444-2450.

[101] Gordaliza, M., Garc'1a, P.A., Miguel, Del, J.M., et al, "Podophyllotoxin: distribution, sources, applications and new cytotoxic derivatives," Toxicon. 44, 2004, 441-459.

[102] Kelly Craven., Grass fungal endophytes and uses thereof, US2012/0144533(Source: http://www.freshpatents.com)

[103] Ezra, D., Castillo, U.F., Strobel, G.A, Coronamycins, peptide antibiotics produced by a verticillate Streptomycessp. (MSU2110) endophytic on Monstera sp. Microbiology. 150, 2004, 785-793.

[104] Brady, S.F., Singh, M.P., Janso, J.E., and Clardy, J, "Cytoskyrins A and B, new BIA active bisanthraquinones isolated from an endophytic fungus, Organic Letters. 2, 2000, 4047-4049.

[105] Isaka, M., Jaturapat, A., Rukseree, K., et al, "Phomoxanthones A and B, novel xanthone dimers from the endophytic fungus Phomopsis species," Journal of Natural Products. 64, 2001,1015-1018.

[106] Diogo, H.E., Sarpieri, A.N., and Pires, M.C, Fungi preservation in distilled water. An, Bras. Dermatol. 80, $2005,591-594$.

[107] Song Li., Ye., Shan., Yang., and Tan, "Endophytic naphthopyrone metabolites are co-inhibitors of xanthine oxidase, SW1116 cell and some microbial growths," FEMS Microbiology Letters. 241, 2004, 67-72.

[108] Rajagopal, R., Suryanarayanan, T.S, Isolation of endophytic fungi from leaves of neem (Azadirachta indica). Curr. Sci. 78, $2000,1375-1378$.

[109] Mahesh, B., Tejesvi, M.V., Nalini, M.S., et al, Endophytic mycoflora of inner bark of Azadirachta indica A. Juss. Curr. Sci. $88,2005,218-219$

[110] Verma, V.C., Gond, S.K., Kumar, A., et al, Endophytic mycoflora of bark, leaf, and stem tissues of Azadirachta indica A. Juss. (neem) from Varanasi (India). Microb. Ecol. ; 54, 2007, 119-125.

[111] .Zikmundova', M., Drandarov, K., Bigler, L., et al, Biotransformation of 2-benzoxazolTolerance of inone (BOA) and 2hydroxy-1,4-benzoxazin-3-one Avena by endophytic fungi isolated from AphelanDegradation Appl. Environ. Microbiol 2002

[112] Zhang, J., Zhang, L., Wang, X, Microbial transformation of 10-deacetyl-7-epitaxol and 1ß-hydroxybaccatin I by fungi from the inner bark of Taxus yunnanensis, Journal of Natural Products .61, 1998,497-5.

[113] Shibuya, H., Kitamura, C., Maehara, S, Transformation of cinchona alkaloids into 1-N-oxide derivatives by endophytic Xylaria sp. Isolated from Cinochona pubescens ,Chem Phar Bull. 51, 2003,71-74.

[114] Simanjuntak, P., Prana, T.K., Wulandari, D., et al, Chemical studies on a curcumin analogue produce by endophytic fungal transformation , Asian Journal of Applied Sciences. 3, 2010,60-66.

[115] Bastos, D.Z.L., Pimentel, I.C., Dykstra, C., et al, Fungos associadosa' casca do caule de Platanus orientalis L. Estudos de Biologia. 26, 2004, 37-41.

[116] Dandu Anitha., Tartte Vijaya., Netala Vasudeva Reddy., et al, microbial endophytes and their potential for improved bioremediation and biotransformation, Indo American Journal of pharmaceutical Research.3, 2013, 2231-6876.

[117] Guo, L.D., Hyde, K.D., Liew, E.C.Y, A method to promote sporulation in palm endophytic fungi. Fungal Divers. 1, 1998, $109-113$.

[118] Guo, B., Dai, J.R., Ng, S., Huang, Y., et al, Cytonic acids A and B: novel tridepside inhibitors of hCMV protease from the endophytic fungus Cytonaema species. J Nat Prod. 63, 2000,,602-604.

[119] Song, Li., Ye., Shan., Yang., and Tan, "Endophytic naphthopyrone metabolites are co-inhibitors of xanthine oxidase, SW1116 cell and some microbial growths," FEMS Microbiology Letters. 241, 2004, 67-72.

[120] Ghimire, S.R., Charlton, N.D., Bell, J.D., et al, Biodiversity of fungal endophyte communities inhabiting switchgrass (Panicum virgatum L.) growing in the native tallgrass prairie of northern Oklahoma. Fungal Divers. 47, 2011,19-27. 
[121] Kirchhof, G., Reis, V.M., Baldani, J.I., et al, A Occurrence, physiological and molecular analysis of endophytic diazotrophic bacteria in gramineous energy plants. Plant Soil. 194, 1997, 45-55.

[122] Morakotkarn, D., Kawasaki, H., Seki, T, Molecular diversity of bamboo-associated fungi isolated from Japan. FEMS Microbiol Lett. 266, 2007,10-19.

[123] Götz, M., Nirenberg, H., Krause, S., et al, Fungal endophytes in potato roots studied by traditional isolation and cultivation-independent DNA-based methods. FEMS Microbiol Ecol. 58, 2006, 404-413.

[124] Ding, Z., Liu, Z., Guo., and Che, "Photinides A-F, cytotoxic benzofuranone-derived $\gamma$ - lactones from the plant endophytic fungus Pestalotiopsis photiniae," Journal of Natural Products. 72, 2009,942-945.

[125] Margulies, M., Egholm, M., Altman, W.E., et al, Genome sequencing in microfabricated highdensity picolitre reactors. Nature .437, 2005,376-380.

[126] Gharizadeh, B., Norberg, E., Löffler, J., et al, Identification of medically important fungi by the Pyrosequencing (TM) technology. Mycoses. 47, 2004,29-33.

[127] Ovaskainen, O., Nokso-Koivista, J., Hottola, J., et al, Identifying wood-inhabiting fungi with 454 sequencing - what is the probability that BLAST gives the correct species? Fungal Ecol. 3, 2010, 274-283.

[128] Azevedo., Maccheroni., Pereira., and de Araujo, Endophytic microorganisms: A review on insect control and recent advances on tropical plants. Electron. J. Biotechnol. ; 3 ,2000.

[129] Lacava, P.T., Li, W.B., Araujo, W.L., et al, Rapid, specific and quantitative assays for the detection of the endophytic bacterium Methylobacterium mesophilicum in plants. J. Microbiol Methods. 65, 2006,535-41.

[130] Wen Cy., Wu, Y.H., Tian, X.D, Recent advances and issues on the endophyte J. Chinese Journal of Ecology In (Chinese).23, 2004, 86-91.

[131] Strobel, G, "Endophytes as sources of bioactive products," Microbes and Infection. 5 ,535-544.

[132] Wang, J, Study and Application on Endophyte. Qinghai Prataculture (In Chinese), ; 17, 2003,24-28.

[133] Wen Cy., Wu, Y.H., Tian, X.D, Recent advances and issues on the endophyte J. Chinese Journal of Ecology In (Chinese). 23, 2004,86-91.

[134] Puri, S.C., Verma, V., Amna, T., et al, An endophytic fungus from Nothapodytes foetida that produces camptothecin. J. Nat. Prod. 68, 2005, 1717-1719

[135] Kusari. S., Z"uhlke., and M, Spiteller, "An endophytic fungus from Camptotheca acuminata that produces camptothecin and analogues," Journal of Natural Products. 72 , 2009,2-7.

[136] Kour, A., Shawl, A.S., Rehman, S., et al, Isolation and identification of an endophytic strain of Fusarium oxysporum producing podophyllotoxin from Juniperus recurva. World Journal of Microbiology and Biotechnology. 24, 2008 , $1115-1121$.

[137] Stinson, M., et al, An endophytic Gliocladium sp. of Eucryphia cordifolia producing selective volatile antimicrobial compounds. Plant Sci. 165, 2003, 913-922.

[138] Miller, C.M., Miller, R.V., Garton-Kenny, et al, Ecomycins., unique antimycotics from Pseudomonas viridiava. J Appl Microbiol. 84, 1998, 937-944.

[139] Errol, R., Thom., Alison, J., Popay., et al, Evaluting the performance of endophytes in farm systems to improve framer outcome-a review.Crop and Pasture Science,63, 2013.

[140] Castillo, U.F., Strobel, G.A., Ford, E.J, Munumbicins, wide-spectrum antibiotics produced by Streptomyces NRRL30562, endophytic on Kennedia nigriscans. Microbiology. 148, 2002, s 2675-2685.

[141] Gary, A., Strobel, A naphthalene producing endophytic fungus M.vitigenus, US 7,267,975. (Source: http://plantsciences.montana.edu/facultyorstaff/faculty/strobel/patents.html).

[142] Gary, A., Strobel, Endophytic streptomycetes from higher plants with biological activity, US 7,259,004. (Source: http://plantsciences.montana.edu/facultyorstaff/faculty/strobel/patents.html

[143] Gary, A., Strobel, Taxol from T.andrenae and other endophytes US5,861,302;5322,779;;5,908,759;5,916,783;5,958,741; and 6,013,493. (Source: http://plantsciences.montana.edu/facultyorstaff/faculty/strobel/patents.html)

[144] Joan, M., Hepson, Use of endophytic fungi to treat plant US 7, 232, 565, B2.(Source: http://www.freshpatents.com)

[145] Brain, Anthony, tapper, Grass endophytes patents no: US 2011/0262401A1. (Source: http://www.freshpatents.com)

[146] John, David, Miller., and Greg, William, Adams, Endophyte enhanced seedling with increase pest tolerance, US 2011/0173727. (Source: http://www.freshpatents.com)

[147] Maurice, Philip, Rolston, Grass based avain deterrent, US 2012/0087897.(Source: http://www.freshpatents.com)

[148] Kelly, Craven, Grass fungal endophytes and uses thereof, US2012/0144533.(Source: http://www.freshpatents.com)

[149] John, David, Miller, Antifungal metabolites from fungal endophytes of pinus strobus, US2012/0198590.(Source: http://www.freshpatents.com)

[150] German, Carlos, Spangenberg., et al, Endophytes and related methods, US2013/0104263.(Source: http://www.freshpatents.com)

[151] Latch, Garrick, Cecil, Morland, Tall fescue endophytes, US6111170A. (Source: http://www.freshpatents.com)

[152] Brain, Anthony, tapper, Improvement in grass endophytes patents no: WO2004106487A2. (Source: http://worldwide.espacenet.com)

[153] Brain, Anthony, tapper., Method for protecting grass using an endophyte, patents no: EP2636302 A1.(Source: http://worldwide.espacenet.com)

[154] German, Carlos, Spangenberg., et al, Endophytes and related methods, US2013/0104263. (Source: http://www.freshpatents.com)

IOSR Journal of Biotechnology and Biochemistry (IOSR-JBB) is UGC approved Journal with Sl. No. 4033, Journal no. 44202.

Shashank A. Tidke. "Current Understanding of Endophytes: Their Relevance, Importance, and Industrial Potentials." IOSR Journal of Biotechnology and Biochemistry (IOSR-JBB) 3.3 (2017): 43-59. 